\title{
Release of metal ions from round and rectangular NiTi wires
}

\author{
Arash Azizi ${ }^{1}$, Abdolreza Jamiliann ${ }^{2 *}$, Francesca Nucci ${ }^{3}$, Zinat Kamali ${ }^{4}$, Nima Hosseinikhoo ${ }^{5}$ and Letizia Perillo ${ }^{6}$
}

\begin{abstract}
Background: The aim of this study was to evaluate the amount of nickel and titanium ions released from two wires with different shapes and a similar surface area.

Methods: Forty round nickel-titanium (NiTi) arch wires with the diameter of $0.020 \mathrm{in}$. and 40 rectangular NiTi arch wires with the diameter of $0.016 \times 0.016 \mathrm{in}$. were immersed in artificial saliva during a 21-day period. The surface area of both wires was $0.44 \mathrm{in}^{2}$. Wires were separately dipped into polypropylene tubes containing $50 \mathrm{ml}$ of buffer solution and were incubated and maintained at $37{ }^{\circ} \mathrm{C}$. Inductively coupled plasma atomic emission spectrometry (ICP-AES) was used to measure the amount of ions released after exposure lengths of $1 \mathrm{~h}, 24 \mathrm{~h}, 1$ week, and 3 weeks. Repeated measures ANOVA and Tukey tests were used to evaluate the data.
\end{abstract}

Results: The results indicated that the amount of nickel and titanium concentrations was significantly higher in the rectangular wire group. The most significant release of all metals was measured after the first hour of immersion. In the rectangular wire group, $243 \pm 4.2 \mathrm{ng} / \mathrm{ml}$ of nickel was released after $1 \mathrm{~h}$, while $221.4 \pm 1.7 \mathrm{ng} / \mathrm{ml}$ of nickel was released in the round wire group. Similarly, $243.3 \pm 2.8 \mathrm{ng} / \mathrm{ml}$ of titanium was released in the rectangular wire group and a significantly lower amount of $211.9 \pm 2.3 \mathrm{ng} / \mathrm{ml}$ of titanium was released in the round wire group.

Conclusions: Release of metal ions was influenced by the shape of the wire and increase of time.

\section{Background}

Orthodontic appliances are made of alloys containing nickel, cobalt, and chromium in different percentages. Thermal, microbiologic, and enzymatic properties of the oral environment make it an ideal place for the biodegradation of these alloys. Metals used as components of these alloys, i.e., nickel and chromium, have been identified as cytotoxic, mutagenic, and allergenic [1]. In addition, nickel is the most common cause of metal-induced allergic contact dermatitis and produces more allergic reactions than all other metals combined, followed by chromium [2]. It has been shown that the level of nickel in saliva and serum increases significantly after the insertion of fixed orthodontic appliances [3]. Nickel-titanium (NiTi) wire is one of the most common orthodontic wires applied clinically due to its good working and mechanical properties; however, nickel-titanium wires may contain in excess of

\footnotetext{
* Correspondence: info@jamilian.net

Department of Orthodontics, Tehran Dental Branch, Craniomaxillofacial Research Center, Islamic Azad University, No 2713, Vali Asr St., Tehran 1966843133, Iran

Full list of author information is available at the end of the article
}

$50 \%$ nickel, while stainless steel wires contain only $8 \%$ nickel [4-6].

Previous studies have investigated, both in vitro and in vivo, release of metal ions from orthodontic appliances [3, 7-11]. Mikulewicz et al. [12] found that the use of fixed orthodontic appliances made of stainless steel can be a source of risk exposure to nickel. Huang et al. [13] reported that the manufacturer, $\mathrm{pH}$, and immersion period had a statistically significant influence on the release amount of nickel and titanium ions from commercial NiTi wires in acidic artificial saliva. Kuhta et al. [14] studied the effects of wire type on the release of metal ions and found that release of metal ions was influenced by composition of the orthodontic arch wire, but this was not proportional to the content of metal in the wire. An electronic search in the literature reveals that no information exists about the effects of different cross sections of different wires on the release of $\mathrm{Ni}$ and $\mathrm{Ti}$ ions. The aim of this study was, therefore, to compare the effects of round and rectangular $\mathrm{NiTi}$ wires and different immersion times on the release of $\mathrm{Ni}$ and $\mathrm{Ti}$ ions in artificial saliva.

\section{(9) Springer}

(C) 2016 Azizi et al. Open Access This article is distributed under the terms of the Creative Commons Attribution 4.0 International License (http://creativecommons.org/licenses/by/4.0/), which permits unrestricted use, distribution, and reproduction in any medium, provided you give appropriate credit to the original author(s) and the source, provide a link to the Creative Commons license, and indicate if changes were made. 


\section{Methods}

Eighty orthodontic NiTi arch wires with round and rectangular cross sections were used in this study (Ortho Technology, Tampa, FL, USA). Both wires were 7 in. long. Group 1 consisted of 40 round $\mathrm{NiTi}$ arch wires with the diameter of 0.020 in., and group 2 included 40 rectangular $\mathrm{NiTi}$ arch wires with the diameter of $0.016 \times 0.016 \mathrm{in}$. The surface area of both wires was 0.44 in. $^{2}$. Each group was divided into four equal subgroups for four different time points. The testing solution used in the present study was artificial saliva (Sinphar Pharmaceutical Co., Ltd, Taipei, Taiwan) which was adjusted with $1 \mathrm{mM} \mathrm{NaHNO}$ to $\mathrm{pH} 6.75 \pm 0.15$ buffer solutions (Table 1 ). Wires were separately dipped into polypropylene tubes containing $50 \mathrm{ml}$ of buffer solution and were incubated at $37{ }^{\circ} \mathrm{C}$ and placed on a shaker to simulate in vivo situation. In this study, we measured the amount of ion released after exposure lengths of $1 \mathrm{~h}, 24 \mathrm{~h}$, 1 week, and 3 weeks.

At the end of each immersion period, $5 \mathrm{ml}$ of eluent was removed from each solution using a syringe with a plastic tip. Inductively coupled plasma atomic emission spectrometry (ICP-AES) was used to determine the amount of $\mathrm{Ni}$ and $\mathrm{Ti}$ ions released after each immersion period.

\section{Statistical analyses}

The release amount of $\mathrm{Ni}$ and $\mathrm{Ti}$ ions at different time points for different cross sections was statistically analyzed by repeated measures ANOVA. Tukey grouping method was used to compare the concentration of $\mathrm{Ni}$ and $\mathrm{Ti}$ released for the different time points and types of wires. All results were analyzed at a significance level of $5 \%$.

\section{Results}

Tables 2 and 3 show the accumulated amount of $\mathrm{Ni}$ and $\mathrm{Ti}$ ions released from rectangular and round NiTi wires after different immersion periods of $1 \mathrm{~h}, 24 \mathrm{~h}, 1$ week, and 3 weeks. The results of the Kolmogorov-Smirnov test showed that all ions had normal distributions.

Table 1 Content of SaliLube (Sinphar Pharmaceutical Co., Ltd, Taipei, Taiwan) artificial saliva

\begin{tabular}{ll}
\hline Content & Amount $(\mathrm{mg})$ \\
\hline Sodium chloride & 0.844 \\
Potassium chloride & 1.2 \\
Calcium chloride anhydrous & 0.146 \\
Magnesium chloride $6 \mathrm{H}_{2} \mathrm{O}$ & 0.052 \\
Potassium phosphate dibasic & 0.34 \\
Sorbitol solution (70 \%) & 60 \\
Methylparaben & 2 \\
Hydroxyethyl cellulose & 3.5 \\
\hline
\end{tabular}

Table 2 Release of nickel in rectangular and round NiTi wires at different time points

\begin{tabular}{llll}
\hline Time & $\begin{array}{l}\text { Rectangular wire } \\
\text { Mean } \pm \text { SD }\end{array}$ & $\begin{array}{l}\text { Round wire } \\
\text { Mean } \pm \text { SD }\end{array}$ & $P$ value \\
\hline $1 \mathrm{~h}$ & $243 \pm 4.2$ & $221.4 \pm 1.7$ & 0.001 \\
$24 \mathrm{~h}$ & $319.4 \pm 2.9$ & $265.1 \pm 2.7$ & 0.001 \\
1 week & $386.1 \pm 3$ & $324.2 \pm 3.6$ & 0.001 \\
3 weeks & $410.6 \pm 2.6$ & $376 \pm 3$ & 0.001 \\
$P$ value & 0.001 & 0.001 & 0.001 \\
\hline
\end{tabular}

After $1 \mathrm{~h}$ of immersion, $243 \pm 4.2 \mathrm{ng} / \mathrm{ml}$ nickel was released from rectangular wires in the artificial saliva while $221.4 \pm 1.7 \mathrm{ng} / \mathrm{ml}$ nickel was released from round wires $(P<0.001)$. Repeated measures ANOVA showed that in all immersion periods, the amount of nickel and titanium released from rectangular wires was significantly higher than the ions released from round wires.

A comparison of nickel and titanium release from both rectangular and round wires at different immersion periods showed that, in all groups, the accumulated amount of metal ions increased with immersion period while the average ion released per day decreased with immersion period. Repeated measures ANOVA showed that the increase of released ions at different immersion periods was statistically significant for all of them $(P<$ 0.001) (Tables 2 and 3). In addition, Tukey test showed that there has been a significant difference between all the time intervals in each group.

\section{Discussion}

The aim of this study was to determine the nickel and titanium release from two different shapes of $\mathrm{NiTi}$ wires by immersion of the samples in artificial saliva. The wires had different cross sections but the same surface area. The cross sections were round and rectangular. In order for the rectangular and round NiTi wires to have the same surface area, 0.020-in. round and $0.016 \times 0.016$ in. rectangular wires were used in this study. The current study showed that with the same surface area, the concentration of $\mathrm{Ni}$ and $\mathrm{Ti}$ ions transferred from rectangular wires to the saliva is significantly higher than that of round wires. The difference

Table 3 Release of titanium in rectangular and round NiTi wires at different time points

\begin{tabular}{llll}
\hline Time & $\begin{array}{l}\text { Rectangular wire } \\
\text { Mean } \pm \text { SD }\end{array}$ & $\begin{array}{l}\text { Round wire } \\
\text { Mean } \pm \text { SD }\end{array}$ & $P$ value \\
\hline $1 \mathrm{~h}$ & $243.3 \pm 2.8$ & $211.9 \pm 2.3$ & 0.001 \\
$24 \mathrm{~h}$ & $288.4 \pm 5$ & $253.7 \pm 3.9$ & 0.001 \\
1 week & $318.8 \pm 1.6$ & $290 \pm 1.6$ & 0.001 \\
3 weeks & $385.6 \pm 4.4$ & $329.5 \pm 6.3$ & 0.001 \\
$P$ value & 0.001 & 0.001 & 0.001 \\
\hline
\end{tabular}


might be due to the fact that cylindrical and rectangular bar shapes with the same surface areas do not have the same volume. The difference might also be due to the different edges of the cross sections. Further research is required to provide evidence for the effect of sharp and round edges on the release of ions into the saliva. The current study also showed that the amount of $\mathrm{Ni}$ and $\mathrm{Ti}$ ions significantly increased in both groups with the passage of time.

$\mathrm{Ni}$ is a widespread component of the Earth's surface. Its presence in food and drinking water is determined by both natural and anthropogenic factors, the latter generically identifiable with industrial and technological sources. $\mathrm{Ni}$ and Ni compounds have been classified as carcinogenic to humans causing cancers of the lung and nasal cavity and paranasal sinuses after inhalation.

Numerous in vitro and in vivo studies have evaluated the release of metals from orthodontic appliances in biologic fluids such as saliva, blood, and urine.

Kuhta et al. [14] analyzed the effects of $\mathrm{pH}$, composition of arch wire, and length of immersion on the release of metal ions from orthodontic appliances and found that release of metal ions was influenced by composition irrespective to the content of metal in the wire. Wataha et al. [15] also reported that although NiTi wires have a high percentage of nickel, the quantity of released nickel ions is smaller than that released from SS wire.

Most studies reported that the measurable amount of metals, released from orthodontic appliances in saliva or blood samples, was significantly below the toxic concentrations [3, 16]. Senkutvan et al. [17] analyzed the rate of $\mathrm{Ni}$ ion release from different types of arch wires used in orthodontics. They found that the quantities of metal ions released in their experimental conditions were not a concern in utilizing the appliance as the amount released was below the critical value necessary to induce allergy and below the daily dietary intake levels of $200-300 \mu \mathrm{g} /$ day. Nonetheless, it cannot be excluded that even nontoxic concentrations might be sufficient to induce important biologic effects in the cells of the oral mucosa [9].

The release of metal ions from orthodontic appliances cannot be fully avoided; however, it would be advisable to use materials with lower amounts of ions released in the mouth. If the clinician has the option of using either round or rectangular NiTi wires, we suggest that round wires be given priority. However, more in vivo experiments are required to firmly determine the levels of dissolved nickel and titanium in different shapes of wires. Future studies with a lower $\mathrm{pH}$ to simulate intraoral conditions present with plaque buildup are also advisable. Comparing the surface roughness between round and rectangular wires from different manufacturers can also be enlightening for clinicians.

\section{Conclusions}

- The release amount of $\mathrm{Ni}$ and $\mathrm{Ti}$ ions increased with immersion period while the average ion released per day decreased with immersion period.

- The amounts of $\mathrm{Ni}$ and $\mathrm{Ti}$ ions released from rectangular NiTi wires in artificial saliva were greater than those in round wires; however, the average amount of ions released per day from both wires was well below the tolerable daily dietary intake level.

Competing interests

The authors declare that they have no competing interests.

\section{Authors' contributions}

$\mathrm{AA}$ and FN were responsible for study design, administration, drafting, critical revision and final approval of the article. ZK was responsible for statistical analysis and data interpretation. AJ and LP was responsible for the study concept, data interpretation, critical revision, writing and revising the report, and final approval of the article. $\mathrm{NH}$ was responsible for conducting the tests in the laboratory. All authors read and approved the final manuscript.

\section{Author details}

${ }^{1}$ Department of Oral and Maxillofacial Medicine, Tehran Dental Branch, Craniomaxillofacial Research Center, Islamic Azad University, Tehran, Iran. ${ }^{2}$ Department of Orthodontics, Tehran Dental Branch, Craniomaxillofacial Research Center, Islamic Azad University, No 2713, Vali Asr St., Tehran 1966843133, Iran. ${ }^{3}$ Dental School, Universidad Alfonso X El Sabio, Madrid, Spain. ${ }^{4}$ National Nutrition and Food Technology Research Institute, Faculty of Nutrition Sciences and Food Technology, Shahid Beheshti University of Medical Sciences, Tehran, Iran. ${ }^{5}$ Tehran Dental Branch, Islamic Azad University, Tehran, Iran. ${ }^{6}$ Multidisciplinary Department of Medical-Surgical and Dental Specialties, Second University of Naples, Naples, Italy.

Received: 27 January 2016 Accepted: 24 February 2016

Published online: 04 April 2016

\section{References}

1. Kolokitha OE, Kaklamanos EG, Papadopoulos MA. Prevalence of nickel hypersensitivity in orthodontic patients: a meta-analysis. Am J Orthod Dentofacial Orthop. 2008;134:722. e1- e12; discussion -3.

2. Bass JK, Fine $\mathrm{H}$, Cisneros GJ. Nickel hypersensitivity in the orthodontic patient. Am J Orthod Dentofacial Orthop. 1993;103:280-5.

3. Agaoglu G, Arun T, Izgi B, Yarat A. Nickel and chromium levels in the saliva and serum of patients with fixed orthodontic appliances. Angle Orthod. 2001;71:375-9.

4. Mattick CR. Current products and practice section: religious, cultural, and ethical dilemmas in orthodontics. J Orthod. 2003;30:88-92.

5. Zinelis S, Al Jabbari YS, Gaintantzopoulou M, Eliades G, Eliades T. Mechanical properties of orthodontic wires derived by instrumented indentation testing (IIT) according to ISO 14577. Prog Orthod. 2015;16:19.

6. Nucera R, Gatto E, Borsellino C, Aceto P, Fabiano F, Matarese G, et al. Influence of bracket-slot design on the forces released by superelastic nickel-titanium alignment wires in different deflection configurations. Angle Orthod. 2014;84:541-7.

7. Eliades T, Trapalis C, Eliades G, Katsavrias E. Salivary metal levels of orthodontic patients: a novel methodological and analytical approach. Eur J Orthod. 2003;25:103-6.

8. Jamilian A, Moghaddas O, Toopchi S, Perillo L. Comparison of nickel and chromium ions released from stainless steel and NiTi wires after immersion in Oral B(R), Orthokin(R) and artificial saliva. J Contemp Dent Pract. 2014;15:403-6.

9. Faccioni F, Franceschetti P, Cerpelloni M, Fracasso ME. In vivo study on metal release from fixed orthodontic appliances and DNA damage in oral mucosa cells. Am J Orthod Dentofacial Orthop. 2003;124:687-93. discussion 93-4.

10. Hafez HS, Selim EM, Kamel Eid FH, Tawfik WA, Al-Ashkar EA, Mostafa YA. Cytotoxicity, genotoxicity, and metal release in patients with fixed orthodontic appliances: a longitudinal in-vivo study. Am J Orthod Dentofacial Orthop. 2011;140:298-308. 
11. Ghazal AR, Hajeer MY, Al-Sabbagh R, Alghoraibi I, Aldiry A. An evaluation of two types of nickel-titanium wires in terms of micromorphology and nickel ions' release following oral environment exposure. Prog Orthod. 2015;16:9.

12. Mikulewicz M, Chojnacka K, Wozniak B, Downarowicz P. Release of metal ions from orthodontic appliances: an in vitro study. Biol Trace Elem Res. 2012;146:272-80.

13. Huang HH, Chiu YH, Lee TH, Wu SC, Yang HW, Su KH, et al. Ion release from NiTi orthodontic wires in artificial saliva with various acidities. Biomaterials. 2003:24:3585-92.

14. Kuhta M, Pavlin D, Slaj M, Varga S, Lapter-Varga M. Type of archwire and level of acidity: effects on the release of metal ions from orthodontic appliances. Angle Orthod. 2009;79:102-10.

15. Wataha JC, Craig RG, Hanks CT. The release of elements of dental casting alloys into cell-culture medium. J Dent Res. 1991;70:1014-8.

16. Kocadereli L, Atac PA, Kale PS, Ozer D. Salivary nickel and chromium in patients with fixed orthodontic appliances. Angle Orthod. 2000;70:431-4.

17. Senkutvan RS, Jacob S, Charles A, Vadgaonkar V, Jatol-Tekade S, Gangurde P. Evaluation of nickel ion release from various orthodontic arch wires: an in vitro study. J Int Soc Prev Community Dent. 2014;4:12-6.

\section{Submit your manuscript to a SpringerOpen ${ }^{\odot}$ journal and benefit from:}

- Convenient online submission

- Rigorous peer review

- Immediate publication on acceptance

- Open access: articles freely available online

- High visibility within the field

- Retaining the copyright to your article

Submit your next manuscript at $\gg$ springeropen.com 